\title{
The Regulation of Natural Resources Law in Australia for Indigenous People
}

\author{
Ros Vickers \\ School of Law Charles Darwin University \\ Ros.Vickers@cdu.edu.au
}

\begin{abstract}
Natural resources law in Australia seeks to regulate, protect and conserve natural resources, while providing consideration to the economic value of projects and permit activities to occur. The same environmental laws apply to indigenous peoples as well as other members of the public in Australia. However the recognition of native title rights and sacred sites through legislation can acknowledge the special relationship that indigenous people have with the environment through traditional laws and customs. Indigenous people have a special relationship with their environment that does not easily fall within categories of western values of the environment, and for this reason there is often tension between the common law legal system and indigenous people. While there has been significant process working towards a more harmonious regulatory system of natural resources, there is still work to be done. This paper will outline the structure of indigenous rights impacting natural resource regulation in Australia, focusing on the Northern Territory, and will examine the origins of environmental law and indigenous rights.
\end{abstract}

Keywords: The Regulation, Natural Resources Law, Indigenous People.

\section{A. Introduction}

The laws that govern natural resources in Australia, and also impact the recognition of Indigenous law and custom can be sourced 
in International Conventions, agreements and treaties. There is a complex relationship between international law and domestic law regarding indigenous peoples and the environment ${ }^{1}$, and while this paper does not seek to exhaustively list every international instrument, principle or norm applicable to indigenous peoples and the environment, it will draw attention to a few key principles of international law which are of particular significance to indigenous peoples and their relationship with the land in Australia.

Indigenous Australians have a complex relationship with the land and natural resources that has proven to provide tensions within the western common law system in Australia. Significant progress has been made to accommodate and recognize indigenous customs, culture and laws within Australia. The following quote highlights a major difference between common law values and indigenous values of land and natural resources.

"There is another dimension that invests land with meanings and significance - which transforms land and environment into landscape, and into 'country'. That other dimension is culture. Culture is what enables us to conceive of land and environment in terms that are different to conventional European notions... 'landscape' and 'environment' are human constructs - they are terms that are inherently shaped by the ways in which humans perceive, or think about the world around them."

Mick Dodson - First Aboriginal and Torres Strait Islander Commissioner (1996)

\section{B. International Law Contributes to The Development of Indigenous Rights in Australia}

Indigenous peoples' right to give their free prior and informed consent to resource development on their traditional lands has emerged

1 Australia does not agree to be bound by an international treaty unless it is satisfied that its domestic laws comply with the terms of the treaty (states can agree to be bound by a treaty by ratifying it or acceding to the treaty. "Ratification" is the process by which a signatory state to a treaty confirms that it intends to be bound by that treaty. This is usually done by the signatory state signing the treaty. 'Accession' occurs when a state, which did not ratify a treaty, formally accepts its provisions). 
as a clear, but controversial, principle of international law. This is commonly understood as a "veto" by indigenous peoples over development on their lands, although there is some debate about what exactly it does mean. Indigenous peoples' right to FPIC is expressly stated in the International Labour Organisation's Indigenous and Tribal Peoples' Convention 1989 (Convention No 169) (but only in the event of relocation of indigenous peoples from their ancestral lands) and in the United Nations Declaration of the Rights of Indigenous Peoples (UNDRIP).

The UNDRIP contains an express obligation for states to:

"Consult and cooperate in good faith with the indigenous peoples ... to obtain their free and informed consent prior to the approval of any project affecting their lands or territories and other resources, particularly in connection with the development, utilization or exploitation of minerals, water or other resources." (Article 31)

FPIC processes are seen as a way of: making "real" indigenous peoples' right to self-determination; and, addressing prior wrongs done to indigenous peoples due to the fact that indigenous people have been historically discriminated against and excluded from decision-making processes. ${ }^{2}$ Convention No 169 is the only international treaty specifically dedicated to indigenous peoples. Australia supported the adoption of Convention No 169 in 1989 but has not ratified it, mainly because indigenous Australian's have not required or pressured the government, perhaps because the convention is not perceived to do enough for indigenous Australians. ${ }^{3}$

The Declaration on the Rights of Indigenous Peoples was adopted by the General Assembly of the United Nations on 13 September 2007, after 20 years of development. It was adopted with 143 countries voting in favour, 11 abstaining and 4 voting against.

2 MacInnes, A., Colchester, M., Whitmore, A., "Free, prior and informed consent: how to rectify the devastating consequences of harmful mining for indigenous peoples", Perspectives in Ecology and Conservation, Volume 15, Issue 3, July-September 2017, p. 152-160

3 Triggs, Gillian, "Australia's Indigenous Peoples and International Law: Validity of the Native Title Amendment Act 1988 (Cth)" [1999] MelbULawRw 16; (1999) 23(2) Melbourne University Law Review 372 
Australia was one of the four countries who voted against the declaration. Subsequently, in 2009 the Australian Government announced its support for the Declaration. This is not a legally binding instrument under international law, but it does "represent the dynamic development of international legal norms and it reflects the commitment of the UN's member states to move in certain directions" (UN press release) $)^{4}$.

\section{Biological Diversity}

Australia has ratified the Convention on Biological Diversity, ${ }^{5}$ also a product of the Rio Summit. The Convention provides an important framework for Australia's integration of natural resources and environment and biodiversity management policies. Article 6 of the Convention obliges all parties to develop and implement national biodiversity strategies and action plans. This almost universally approved Convention also explicitly recognises the contribution indigenous peoples can make to the conservation and management of biological diversity.

Article 8 provides that each contracting party shall, as far as possible and appropriate:

(j) Respect, preserve and maintain knowledge, innovations and practices of indigenous and local communities embodying traditional lifestyles relevant for the conservation and sustainable use of biological diversity and promote their wider application with the approval and involvement of the holders of such knowledge.

Article 10 calls on parties to:

(c) Protect and encourage customary use of biological resources in accordance with traditional cultural practices that are compatible with conservation or sustainable use requirements ...

(d) Support local populations to develop and implement remedial action in degraded areas where biological diversity has been reduced.

4 UN press release dated April 2013, sourced from: https://www.un.org/ esa/socdev/unpfii/documents/FAQsindigenousdeclaration.pdf, accessed on 23 October 2018

5 Convention on Biological Diversity, opened for signature 5 June 1992 (entered into force 29 December 1993) 
These provisions create legal obligations for Australia to respect the knowledge of indigenous peoples in the conservation of biological diversity, to encourage traditional cultural practices in the use of biological resources and to engage indigenous peoples in remedial action.

\section{Rio Declaration on Environment and Development}

In June 1992, the United Nations Conference on Environment and Development adopted by consensus Agenda 21. Chapter 26 of Agenda 21 deals with recognising and strengthening the role of indigenous peoples and specifically provides that their lands should be protected from activities that are environmentally unsound.

The United Nations Conference on Environment and Development also adopted by consensus, the Declaration on Environment and Development '('Rio Declaration') on 13 June 1992, including principle 22:

Indigenous people and their communities and other local communities have a vital role in environmental management and development because of their knowledge and traditional practices. States should recognize and duly support their identity, culture and interests and enable their effective participation in the achievement of sustainable development.

While Agenda 21 and the Rio Declaration do not create international law, they articulate fundamental principles that are emerging norms of environmental law. At the very least, these norms require that Australia's indigenous peoples are assured the right to full consultation and participation in decisions to develop resources on their lands.

The Racial Discrimination Convention was ratified by Australia on 30 September 1975, and implemented in part through the Racial Discrimination Act 1975 (Cth). There is a complex interaction with the Native Title Act, and in particular the provisions setting out how native title has been and can be extinguished.

6 Declaration of the United Nations Conference on Environment and Development (Rio Declaration) (1992) 31 ILM 874 


\section{Australian Laws Affecting Indigenous Peoples and Natu- ral Resources}

The same laws apply to indigenous peoples as those that apply to all private citizens and entities in Australia with respect to the regulation of natural resources. In the Northern Territory, the Environment Protection and Biodiversity Conservation Act 1999 (Cth); Environmental Assessment Act (NT); Environmental Assessment Administrative Procedures (NT); Environment Protection Authority Act (NT); Mineral Titles Act (NT); Petroleum Act (NT); Mining Management Act (NT); Planning Act (NT); and the Territory Parks and Wildlife Conservation Act (NT) all regulate the environment. There are also laws which give indigenous peoples in Australia a special legal relationship with the land and environment, which interact with these laws. Sometimes these laws or legal interests are in harmony with environmental laws and interests and at other times, there may be conflict. The first important step to the recognition of indigenous rights to natural resources is the recognition of property rights.

\section{The Legal Recognition of Aboriginal People's Property Rights in Australia}

In the Northern Territory, Australia there are two legislative regimes which give Aboriginal people property rights: Aboriginal Land Rights (Northern Territory) Act 1976 (over 50\% of land in the NT is Aboriginal land owned under this legislation); and Native Title Act 1993 (Cth) (nearly all the rest of the land in the NT, except for where native title has been extinguished has, or will have native title claims over it). There is a third regime in the Northern Territory which gives Aboriginal people strong rights in land which is the Northern Territory Sacred Sites Act. This paper will examine each of these legislative regimes.

The legal recognition of Aboriginal people's property rights is key within the legal context of Australia as it leads to the availability of other rights, such as land ownership, public participation and consultation and compensation. 
Prior to the landmark case of Mabo, ${ }^{7}$ it was thought that the Crown enjoyed absolute ownership of all lands, and that all rights in land were derived by the Crown. This was built on the assumption that when settled Australia was terra nullius, or "land of no one". However, Aboriginal people were in Australia, there was no doubt, but the dominant view that they were "nomads" who roamed across the landscape with no defined "territories" and did not cultivate their land in any way contributed to the legal fiction that these people had no property rights, thus they did not "own" the land under British law. Thus, there were no treaties with Aboriginal people, and no acknowledgement of their rights in the land mass we now call Australia at the time Australia was settled in 1788 .

\section{The Aboriginal Land Rights (Northern Territory) Act 1976}

Following the work of Edward Woodward QC, who presided as Commissioner in the Aboriginal Land Rights Commission, the Aboriginal Land Rights (Northern Territory) Act 1976 was passed. This legislation is considered the high water mark of indigenous land rights legislation in Australia, if not the world. This Act provided for a statutory process by which Aboriginal people could claim vacant Crown land in the Northern Territory if they could provide they were 'traditional Aboriginal owners'. Reserve lands (such as Arnhem Land Aboriginal land) were automatically transferred to land trusts. Land granted under the Act is transferred to Aboriginal Land Trusts, which hold land for the benefit of traditional Aboriginal owners. As a general rule, anything which occurs on this land requires the consent of the traditional Aboriginal owners, and the direction of the Northern Land Council. So, generally speaking, if a developer wants to do anything on Aboriginal land, it will need to negotiate with the Land Council regarding the grant of any tenure (lease, licence or other form of tenure). The Land Council must consult with traditional owners, who may or may not give their consent to the grant of that tenure.

7 Mabo and ors v. Queensland(No. 2)(1992) 175 CLR 1,3 June 1992 
There are specific provisions regarding exploration and mining in Part IV of the Act. Minerals are reserved to the Crown, with respect to uranium, to the Commonwealth, and with respect to all other interests, to the Northern Territory. ${ }^{8}$

When the Land Rights Act was enacted in 1976, there was a traditional owner veto over any new exploration and mining interests. This applied even where there was an exploration licence, and the holder of that licence subsequently wanted to obtain a mineral lease over the same land. However, there were exceptions - some mining interests were specifically exempted from this scheme (eg Ranger Uranium Mine), and there is provision for the Governor-General to declare that the national interest required that a grant of a mining interest be made, despite lack of Aboriginal consent. In 1987, Part IV was repealed and a new scheme was substituted. Key difference is that now Aboriginal consent is only required before an exploration licence can be granted in respect of Aboriginal land. Once consent has been given, the general rule is that Aboriginal consent to the grant of any further mining interest is not required. So, traditional owners have a veto over exploration, not mining. This provision strengthens the position of the holder of an exploration licence who finds minerals and intends to mine them. There is still a requirement to negotiate a mining agreement with the Land Council (which governs the terms and conditions upon which mining is to occur) but if one cannot be negotiated within 12 months, then either party may request the Minister to refer the matters in dispute to a Mining Commissioner for resolution of those matters by conciliation or arbitration. ${ }^{9}$

Currently, over $50 \%$ of land in the Northern Territory is Aboriginal land owned under the pursuant to this Commonwealth Act. The Northern Territory government cannot access this and and so the ramifications for those seeking to develop land in the Northern Territory can be complex with respect to the interaction between this Act and environmental laws administered by the Northern Territory.

8 s12(2) of the Aboriginal Land Rights (Northern Territory) Act

9 Section 46 of the Aboriginal Land Rights Act 
Essentially any mine, port, or major development on Aboriginal land requires industry to negotiate with the Land Council, and obtain the consent of the traditional Aboriginal owners. The assessment of the project may be undertaken at a Territory or Federal level depending on the nature of the environmental impacts.

\section{Mabo v Queensland (1992) 175 CLR 1}

This landmark case High Court case rejected terra nullius as a basis for denying Aboriginal entitlement to land at common law, and held that a form of native title could survive colonization until extinguished by an exercise of sovereign power by the Crown. Essentially this means that at the time Australia was settled, the Crown didn't acquire full ownership of land, but acquired 'radical title', and the ability, by subsequent acts of sovereign power to extinguish native title. Extinguishment occurs by a valid exercise of sovereign power inconsistent with the continued right to enjoy native title. Examples of common ways to extinguish native title include: by a grant of freehold title to people; grant of leases (including pastoral leases); grant of mining tenements; declaration or proclamation of reserves; or, the dedication of land for public works.

\section{The Native Title Act 1993}

After the Mabo case was decided there was uncertainty about how native title interacted with existing property rights, and about the state's (and for that matter the public's) ability to deal with land in Australia. The Commonwealth government responded by enacting the Native Title Act 1993 (Cth).

The object of the Native Title Act are: ${ }^{10}$

The main objects of this Act are:

(a) to provide for the recognition and protection of native title; and

(b) to establish ways in which future dealings affecting native title may proceed and to set standards for those dealings; and

10 Section 3 of the Native Title Act (Cth)1993 
(c) to establish a mechanism for determining claims to native title; and

(d) to provide for, or permit, the validation of past acts, and intermediate period acts, invalidated because of the existence of native title.

And Native Title is defined in section 223 of the Native Title Act:

(1) The expression native title or native title rights and interests means the communal, group or individual rights and interests of Aboriginal peoples or Torres Strait Islanders in relation to land or waters, where:

a. the rights and interests are possessed under the traditional laws acknowledged, and the traditional customs observed, by the Aboriginal peoples or Torres Strait Islanders; and

b. the Aboriginal peoples or Torres Strait Islands, by those laws and customs, have a connection with the land or waters; and

c. the rights and interests are recognized by the common law of Australia.

Hunting, gathering and fishing covered

(2) without limiting subsection (1), rights and interests in that subsection include hunting, gathering, or fishing, rights and interests.

The above section essentially sets out what needs to be proved to establish native title. In practice, native title claimants make a claim (represented by the Northern Land Council or Central Land Council in the NT) in the Federal Court and need to establish that a traditional system of law and custom still exists, and has continued to exist since sovereignty from 1788. This can be accomplished using evidence of anthropologists, historians, linguists and archaeologists to establish, as well as oral and affidavit evidence of Aboriginal witnesses. ${ }^{11}$ For completeness, once native title has been extinguished by sovereign acts of the state, native title cannot be "revived".

Once native title has been established under the Native Title Act, the claimants are recognized and are given rights pursuant to the "future act" regime and negotiation of agreements. If there is a proposed new development which requires the grant of an interest in

11 Triggs, Gillian "Australia's Indigenous Peoples and International Law: Validity of the Native Title Amendment Act 1988 (Cth)" [1999] MelbULawRw 16; (1999) 23(2) Melbourne University Law Review 372 
land (for example a mining lease, or the grant of a development lease for a port) then a complex set of provisions apply. This is commonly referred to as the "future act regime". The grant of exploration and mining tenements (including oil and gas interests) by the Northern Territory are subject to the "right to negotiate" process under the Native Title Act. ${ }^{12}$ In general, this must be followed to ensure the grant of these titles is valid.

If there is a registered native title claim or a determination of native title then the native title parties have a "right to negotiate" - the obligation is on the parties to negotiate "in good faith" to get the consent of the native title party to the grant of the tenement. This negotiation usually covers royalties, environmental protection, sacred site protection, business development and other matters. If agreement is reached with the native title holders, then agreements are signed with the government and with the relevant mining company. If agreement is not reached within 6 months from the "notification day" (which incorporates a four month period during which relevant native title parties are identified and new claims registered), then any party can apply to the Native Title Tribunal for mediation or a determination. The Native Title Tribunal will conduct an inquiry and will decide whether the act can proceed and under what conditions. In nearly every case which goes to the Tribunal, the Tribunal determines the mining interest can be granted (and usually on less favourable terms than those negotiated in mining agreements). This puts a lot of pressure on native title parties to agree to mining in practice and as a result, the important question therefore arises, does the "right to negotiate" process in the Native Title Act implement the Free Prior and Informed Consent provisions of the UNDRIP?

\section{Northern Territory Aboriginal Sacred Sites Act}

Another example of a legislative regime that recognizes Indigenous people's rights within the regulation of natural resources is the

$12 \mathrm{NB}$ : there are exceptions to this if something called the "expedited procedure" applies which are not covered in this paper 
Northern Territory Aboriginal Sacred Sites Act. This legislation derives authority from the Aboriginal Land Rights Act (Cth) which states that it is an offence to enter, remain on, or desecrate a sacred site throughout the Northern Territory, regardless of land tenure. A sacred site is a place that are sacred to Aboriginal people or which have significance according to Aboriginal tradition. The Sacred Sites Act creates a system for protecting Aboriginal sites by having a register of sacred sites where sites are listed (although they do not need to be registered to be a sacred site); requiring people or companies who want to carry out works on land where there is a sacred site to obtain an Authority Certificate (or approval) from the Aboriginal Areas Protection Authority before they carry out the works; creating criminal offences for using or carrying out works on land on which there is an Aboriginal sacred site (it is a defence to prosecution if the defendant proves that he or she had no reasonable grounds for suspecting that he sacred site was a sacred site).

The Sacred Sites Act provides robust protection to sacred sites by the Aboriginal Areas Protection Authority ("the AAPA"). AAPA successfully charged a mining company with desecration of a sacred site in Aboriginal Areas Protection Authority v OM (Manganese) Ltd. ${ }^{13}$ In that case the defendant's mining development led to the collapse and destruction of the rocky outcrop in the sacred site known as 'Two Women Sitting Down'. The defendant had obtained an authority certificate from the AAPA on the condition that the sacred area not be entered or disturbed. The defendant purported to consult with local Aboriginal custodians to obtain consent to mine at a steeper angle of the pit wall, closer to the sacred site, even though the custodians did not themselves have individual authority to approve a mining plan that posed a risk to the state of the sacred site. The magistrate held that the defendant had desecrated the site and imposed a fine of $\$ 150,000$.

Legislation as robust as the Sacred Sites Act can militate against box-ticking 'consultation' and 'consent' without meaningful expla-

13 Aboriginal Areas Protection Authority v OM (Manganese) Ltd. 
nation and engagement with Aboriginal communities. The fact that the Act is administered by a dedicated Aboriginal body provides an element of ownership and control to Aboriginal groups that is lacking in other States and Territory legislation. The Sacred Sites Act also creates potential for protection of intangible cultural heritage. In the OM case, the Court noted that the definition of desecration included "not so much the physical integrity of the site bu... whether what has occurred in relation to it has violated the sacred symbols or beliefs that it represents.

Other relevant legislation in the Northern Territory for the protection of indigenous heritage includes the Environment Protection and Biodiversity Conservation Act 1999 (EPBC Act) and the Aboriginal and Torres Strait Islander Heritage Protection Act 1984. The first Act establishes the National Heritage List, which includes natural, Indigenous and historic places that are of outstanding heritage value to the nation. Under the EPBC Act there are penalties for anyone who takes an action that has or will have a significant impact on the indigenous heritage values of a place that is recognised in the National Heritage List. The Aboriginal and Torres Strait Islander Heritage Protection Act 1984_can protect areas and objects that are of particular significance to Aboriginal people. The TSIHP Act allows the Environment Minister, on the application of an Aboriginal person or group of persons, to make a declaration to protect an area, object or class of objects from a threat of injury or desecration.

\section{Litigation Involving Indigenous Peoples and Environ- mental Law}

The existence of native title, or the ownership of land by traditional owners under the Aboriginal Land Rights (Northern Territory) Act, is significant to environmental law because there may be different regimes that may be applied to the management of the land and its natural resources by Aboriginal landholders. This may or may not be in harmony with environmental laws and can result in litigation. Aboriginal people are legally recognized as stakeholders any land 
proposals affecting their traditional lands (including major developments such as mines) and may need to be consulted, or indeed provide their consent to such proposals.

However, in order to access the justice system through the Courts, one needs to establish that they have the right to be heard by the Court, this is known as 'standing'. The case of Onus v Alcoa of Australia (1981) 36 ALR 425 recognised the special role Aboriginal people have with sacred sites. The case was about a whether or not a group of Aboriginal people were about to have their case heard in the Courts, regarding rights under an Act that made it an offence to damage an Aboriginal relic. The group claimed that Aboriginal relics would be destroyed by the construction of an aluminum smelter in Victoria. The High Court unanimously held that the Aboriginal people did have standing as an Aboriginal cultural interest was sufficient to give the appellants standing to challenge the construction of an alumina refinery on sacred land. The reasons of Gibbs CJ were determined to have standing for three reasons: 1) Cultural and spiritual significance; 2) Group was custodian of relics, and; 3 ) and group used them regularly.

Further it was established the Aboriginal people were descents of the traditional occupants and guardians of the site and this gave the appellants "an interest ... which is greater than that of other members of the public and indeed greater than that of other persons of Aboriginal descent who are not members of the Gournditchjmara people...". This case was determined before native title was recognized in Australian legislation.

\section{E. Tensions and Accommodations between Natural Re- source Laws and Indigenous Laws}

A prima facie tension can exist between natural resource regulations and indigenous customs. Generally speaking natural resource management laws are usually the domain of the states and territories. The Northern Territory has its own laws concerning fisheries utilization and protection and fauna protection, which create criminal 
offences for breaches of the legislation, many of which are strict liability offences. The question arises about how does this legislation interact with native title rights?

Section 211 of the Native Title Act provides that native title holders can continue to engage in traditional activities which are in exercise or enjoyment of their native title rights and interests or for the purpose of satisfying their personal, domestic or non-commercial communal needs despite a law of the Commonwealth, a state or a territory which would otherwise prohibit those activities. This section was tested in the case of Yanner v Eaton (1999) 105 LGERA 71, The appellants, whose claims had been denied in the Court of Appeal in Queensland, had used a traditional form of harpoon to catch two juvenile estuarine crocodiles in the Gulf of Carpentaria area of Queensland. Under relevant Queensland law, it was an offence to take such animals without a permit, which the appellant did not have. It was argued that pursuant to s211 of the Native Title Act, the native title holder had a defence to Queensland legislation because he was exercising his native title right to hunt crocodiles. The Queensland legislation declared that all fauna was to be regarded as the property of the Crown. Queensland asserted that this meant that the Crown gained full beneficial ownership of fauna in Queensland, therefore any existing native title rights to fauna must have been extinguished. High Court assessed that the purpose of the regulation had been to establish a royalty regime, not to take property over wild animals for all purposes. Those rights were less than the rights of full beneficial, or absolute, ownership; the claimed right had not been extinguished and was subsequently protected by the Native Title Act.

At 83 of the judgment:

... regulating the way in which rights and interests may be exercised is not inconsistent with their continued existence. Indeed, regulating the way in which a right may be exercised presupposes that the right exists. No doubt, of course, regulation may shade into prohibition and the line between the two may be difficult to discern. ${ }^{14}$

Native title rights rights are supplemented by provisions in Ter-

14 Paragraph 83 of the judgement of Yanner $v$ Eaton (1999) 105 LGERA 71 
ritory Parks and Wildlife Conservation Act 1976 (NT) and Fisheries Act (NT) in the NT which protect traditional rights of hunting and fishing in certain contexts. The Territory Parks and Wildlife Conservation Act 1976 (NT) states specifically in s 53 that the Act does not limit the right of Aboriginal people who have traditionally used an area of land or water from continuing to use that area in accordance with Aboriginal tradition for hunting, food gathering (otherwise than for the purpose of sale) and for ceremonial and religious purposes. The operation of the Act is stated explicitly to be subject to the Native Title Act. Aboriginal tradition has the same meaning as the Aboriginal Land Rights (Northern Territory) Act 1976 (Cth).

The Fisheries Act 1976 (NT) states in s 53(1) that:

(1) Unless and to the extent to which it is expressed to do so but without derogating from any other law in force in the Territory, nothing in a provision of this Act or an instrument of a judicial or administrative character made under it shall limit the right of Aboriginals who have traditionally used the resources of an area of land or water in a traditional manner from continuing to use those resources in that area in that manner.

In the case of Talbot $v$ Malogorski $i^{15}$ the defendant was charged with two offences under the Fisheries Act 1976 (NT). The first offence was for possession of a rod and line with a lure in a closed area which was contrary to the Barramundi Fishing Management Plan; and the second offence for taking two barramundi in a closed (no fishing) area. The defendant gave evidence before the magistrate that he had fished at that particular place all his life and he was taught to catch enough fish only for him and his family's needs by an Aboriginal elder from that area. The defendant's wife also gave evidence of her Aboriginal connection to the area and contact with the elder as a person she believed to be a traditional owner of lands and water of the Limilngan clan. The defendant also called anthropological evidence of traditional Aboriginal practices. The magistrate was satisfied that the appellant was a biological descendant of the Limilngan people who occupied and traditionally used the area. He also concluded that the evidence did not establish that the defendant and the

15 Talbot v Malogorski [2014] NTSC 5 
persons through whom he traced descent continued uninterrupted to observe traditional laws and customs of those people. The magistrate found that native title rights were not established for the place where the fishing took place, which was required in order for the defendant to rely on s 53(1). The defendant was convicted. The magistrate did hold that the defendant was fishing for his personal and domestic needs within the meaning of the Native Title Act and this was a use of the resources of the area in a traditional manner within the meaning of s 53(1) but found the offence proved.

The defendant appealed to the Supreme Court of the Northern Territory. The Court considered the application of s 53(1) and held that a native title right was not determinative of whether s 53(1) applied. Section 53 provides permission to Aboriginal persons to fish in a traditional manner in accordance with s 53(1) subject to its limitations. Such rights are not defined solely by native title rights. The proof of the matters in the section are what is essential to a defence being established. A defendant who seeks to rely on s 53(1) is required to satisfy the Court on the balance of probabilities that he or she comes within its terms. It is not incumbent on the prosecutor to negative any element of the defence or exception beyond reasonable doubt. The defendant's conviction was overturned.

\section{F. Genetic Resources}

The emerging area of rights to genetic resources is gaining traction in Australian legislation, however to date the legislative response has been somewhat piecemeal with multiple regimes at a Commonwealth and State and Territory level. The result is an inconsistent approach across Australia. ${ }^{16}$

\section{G. Conclusion}

The conflicts arising between a Western legal system incorporating and property reflecting Aboriginal cultural knowledge and rights are

16 Mc Cormack, P, Biodiversity Conservation Law and Climate Change, (2018) 92 ALJ 839 
obvious in Natural Resources management laws in Australia. The inclusion of aboriginal knowledge and consultation processes being included in environmental impact decisions can be reflected in environmental impact statements. It is usually a requirement to undertake a "social impact assessment", but other more explicitly "scientific" matters are generally given more weight by decision makers.

However, Aboriginal environmental knowledge is gaining more traction in the following areas Traditional Aboriginal burning practices are increasingly recognized as beneficial to the environment, and have been incorporated into "mainstream" land management practices and indeed into profitable carbon farming initiatives - see the explosion of "indigenous rangers" in Australia managing their traditional lands, Aboriginal rangers increasingly used in patrolling and monitoring of the coastline, and animal and plant species in the Northern Territory, Development of indigenous wildlife enterprises - eg crocodile egg harvesting, Kakadu plum harvesting.

Whilst Indigenous peoples and environmental law provisions do not always have the same agreed outcomes, that is they can differ between environmental outcomes and culturally, social or economically appropriate outcomes, the laws and processes do acknowledge this tension and develop together. The tension in the relationship between land tenure and environmental law is key to govern the interaction with natural resource management.

\section{Bibliography}

\section{Legal Documents}

Australia, Northern Territory, the Environment Protection and Biodiversity

Australia, Northern Territory, The Aboriginal and Torres Strait Islander Heritage Protection Act 1984

Australia, the Northern Territory Aboriginal Sacred Sites Act.

Asutralia, The Native Title Act 1993

Australia, Northern Territory Aboriginal Sacred Sites Act

Conservation Act 1999 (EPBC Act) 
Mabo and ors v. Queensland (No. 2)(1992) 175 CLR 1,3 June 1992

Paragraph 83 of the judgement of Yanner v Eaton (1999) 105 LGERA 71

s12(2) of the Aboriginal Land Rights (Northern Territory) Act

Section 46 of the Land Rights Act

Section 3 of the Native Title Act (Cth)1993

\section{Book and Journal}

Aboriginal Areas Protection Authority v OM (Manganese) Ltd.

MacInnes, A., Colchester, M., Whitmore, A., 2017, "Free, Prior and Informed Consent: How to Rectify the Devastating Consequences of Harmful Mining for Indigenous Peoples'," Perspectives in Ecology and Conservation, Volume 15, Issue 3, July-September.

McCormack, P, 2018, Biodiversity Conservation Law and Climate Change, 92 ALJ 839

Triggs, Gillian, 1999, "Australia's Indigenous Peoples and International Law: Validity of the Native Title Amendment Act 1988 (Cth)" [1999] MelbULawRw 16; 23(2) Melbourne University Law Review 372

UN press release dated April 2013, sourced from: https://www. un.org/esa/socdev/ unpfii / documents / FAQsindigenousdeclaration.pdf, accessed on 23 October 2018 